\title{
Development of Banking Activities in Emerging Market Economy Countries
}

\author{
Otgontugs Narangua
}

BA in Economics, International Finance Faculty, Department of the World Economy and International Finance, Financial University, Moscow, Russia. Scientific advisor A.S. Fedunin, Ph.D. in Economics, Associate Professor, Department of the World Economy and International Finance, Financial University, Moscow, Russia

\begin{abstract}
This paper aims to understand the development of banking activities in emerging market economies not only for evaluating the impact of them for encouraging emerging economies' growth, but also establish the overall effect of these processes to the global financial market. The object of study is the banking activities of emerging market economies, and the subject is the impact of banking activities development on the economic growth of emerging market economies. The author substantiated the thesis that for emerging market economies' financial development should be examined in terms of banking stability, competition, and economic growth. The author also reveals specific characteristics that distinguish banking activities of emerging market economies from developed countries by evaluation of bank performance using criteria of stability, profitability, and efficiency. Keywords: banking activities; emerging market economy; banking crises; financial crisis of 2008 JEL Classification: G21, G28

(c) Otgontugs Narangua, 2020
\end{abstract}

\section{Introduction}

Over the last decades, the banking sector worldwide transformed continually. The substantial transformation of banking activities was triggered by numerous changes in national and global level such as technological development, international competition, deregulation of financial services, banking crises, privatisation of state-owned banks, and others. Notably, during the last few years, the role of the emerging economy in the world economy is increasing substantially due to its economic growth, industrial potentials and a massive supply of resources and labour to the advanced economy countries. As most of these transitions take place in emerging economies, and the role of those countries boosts, it is highly valuable to understand the development of banking activities in emerging market economies not only for evaluating the impact of them for encouraging emerging economies' growth, but also establish the overall effect of these processes to the global financial market. In the context of banking activities of emerging market economies, the historical impact of its development, current trend and its impact in economic potential should be highlighted in advance.

The global financial crisis of 2008 has shown the importance of a sound and profitable banking industry in developed, developing, and emerging countries as well. But in comparison with banks in a developed and developing market, banks of the emerging market were impacted by the crisis in less extend due to the prudent policy and healthy macroeconomic condition. Thus, emerging market economies' banking performance should be measured and sustained at an appropriate level to secure from negative consequences. The current research mostly highlighted the importance of emerging countries' banking stability and profitability on the economic growth of the country. In recent years, there has been an increasing number of studies conducted in examining the relationship between financial development and economic growth and established a direct relationship between them. But as for emerging market economies' financial development should be examined in terms of banking stability, competition, and 
economic growth. There are many articles and research are conducted for evaluating the current trends in the banking sector and its relationship with economic growth, which mostly concerns countries with developing economies. Whereas previously, most of the works are highlighted the development process of banking activities in developed countries and revealed positive trends in economic growth and productive capacity of the individual country.

The current trend in the analysis of many types of research is concentrated on banking activities of emerging economies of Asia, Latin America and Sub-Saharan Africa and its impact on encouraging economic and financial growth to the global level. Also, because of deregulation and liberalisation, the number of foreign banks in emerging market economies increased by 74 per cent and their market share doubles between 1995 and 2009. Currently, the trends continue with more moderated pace, but the role of them in the development of emerging market economies' banking sector is irreplaceable. The number of studies conducted on the problem concentrated on two opposing opinions stating the foreign banks either encourage overall efficiency or cause financial instability. Despite a massive literature on this topic, the risk foreign banks impose on emerging market countries' domestic banks should be evaluated in advance.

The primary goal of this research work is to evaluate the extent of development of banking activities in emerging market countries and provide an analysis of the performance of emerging market banks. The objective of assessing modern trends in the development of banking activities of emerging economy countries and establishing the role of them in encouraging economic and financial growth in the rough competition of global market would be performed by use of different statistical and non-statistical methods. Moreover, the object of study is banking activities of emerging market economies, and the subject is the impact of banking activities development on the economic growth of emerging market economies. For the accomplishment of the goal of this paper, the following tasks should be fulfilled:

To observe current trends in development and determinants that characterise banking activities of emerging market economy countries
To reveal specific characteristics that distinguish banking activities of emerging market economies from developed countries

To evaluate bank performance using stability, profitability, and efficiency

To establish relationship and effect of banking activities development and economic growth for emerging market economies

To determine any characteristic differences of banking activities' development for emerging economies and developed economies

To present a practical example by analysing trends and relationships for emerging economies region and a particular country.

\section{The Banking Sector in Emerging Market Economies}

\section{Main Determinants of Banking Activities Development in Emerging Market Economies}

Much improved economic fundamentals stimulated emerging market banks to join the ranking of the largest banks in the world. Emerging-market banks are growing faster than banks in developed and developing countries. In 2018, 10 of the world's 50 largest banks by market capitalisation come from emerging markets and together merging market banks account for one-third of global banking revenues ${ }^{1}$. Whereas 50 of the world's top banks by asset 12 is from emerging economies, i.e. all of them from China ${ }^{2}$. Chinese banks dominate the largest banks of the world, i.e. from top 100 banks, 20 are Chinese, 5 Brazilian and 5 South Korean. Table 1 presents the largest banks of the world from emerging market economies in terms of market capitalisation and assets.

The banking activities are one of the most important achievements of economic civilisation in the financial intermediation process, which encompasses multiple tools for regulating and maintaining the stability of the whole economy. The banking activities perform five functions which are providing information on allocation of resources, facilitating the exchange of goods

\footnotetext{
${ }^{1}$ Biggest Banks in the World 2018, Global Finance Magazine, 2018. https://www.gfmag.com/magazine/november-2018/biggest-banks-world-2018.

${ }^{2}$ Top 100 banks in the world, 2018. Bank around the world, 2018. https://www.relbanks.com/worlds-top-banks/assets.
} 
Table 1

World's largest banks from emerging market economies 2018

\begin{tabular}{clccc}
\hline N & \multicolumn{1}{c}{ Company name } & Country & $\begin{array}{c}\text { Market capitalisation, } \\
\text { billion \$ }\end{array}$ & Assets, million \$ \\
\hline 1. & $\begin{array}{l}\text { Industrial and Commercial Bank } \\
\text { of China }\end{array}$ & China & 308.63 & $4,006,242$ \\
2. & China Construction Bank & China & 253.3 & $3,397,688$ \\
3. & Agricultural Bank of China & China & 181.4 & $3,233,212$ \\
4. & Bank of China & China & 167.89 & $2,989,653$ \\
5. & China Development Bank & China & 121.67 & $2,450,812$ \\
6. & Bank of Communications & China & 64.54 & $1,388,024$ \\
7. & China Merchants Bank & China & 110.84 & 967,141 \\
8. Itau Unibanco Holding & Brazil & 71.19 & 901,764 \\
9. Industrial Bank & China & 43.63 & 985,448 \\
10. & Banco Bradesco & Brazil & 49.84 & 897,512 \\
\hline
\end{tabular}

Source: Global Finance Magazine, 2018.

and services, encouraging trading and risk diversification, pooling and mobilising deposits, and monitoring investments. Therefore, banking activities development defines the efficiency of conducting these functions. The number of literature and studies highlight the irreplaceable role of banking activities in an increase in economic productivity and efficiency of companies. The banking sector development differs from country to the country depending on economic growth, openness to trade and capital, financial and political institutions, income level, geographical endowments, and human capital. Thus, establishing what makes banking sector to develop is essential to encourage economic growth for specific countries.

The banking activities are multi-dimensional by its nature, and evaluating determinants of its development is complicated. In many empirical studies, gross domestic products (GDP) is used as the primary determinant of banking sector development. Still, the single measure is not enough to provide comprehensive information on the development of a multi-dimensional phenomenon. Measuring the development of the financial sector and particularly the banking sector is complicated and mainly depends on the development of the financial system of the concrete country. Feyen and Levine, in their work, identified four dimensions of banking sector development as depth, access, efficiency, and stability (Feyen \& Levine, 2013, pp.17-21). As for emerging economies' banking, the measures of depth, efficiency and stability are more sensitive. Thus, the composition of different indicators is required to be used in determining banking activities development. Banking activities development as a critical element of economic growth can be estimated by the used of numerous theories including endowment theory, law and finance theory, financial liberalisation theory, interest group theory, inflation, and finance theory. All these theories identify and highlight determinants that either promote or deter banking activities development.

First, the endowment theory states the significance of institutions in banking activities development and emphasises the dependence of the quality of banking activities upon its development (Filippidis \& Katrakilidis, 2014, pp. 501-507). This theory examines institution and geography as the main determinants of banking activities development. As for emerging countries the geographic location is closely interrelated to its development, i.e. the countries that are in borders of developed and developing countries which provides possibilities to share knowledge, experience, and practices to improve institutions. The theory stipulates two assumptions:

The historical conditions do not influence the formation of institutions, and current institutions are independent of a historical one 
The influence of historical conditions on current formation and development still exists.

The developed financial institutions primarily decrease the cost faced by economic agents which increase the efficiency of the banking sector. The significance of financial institutions in the development of banking activities was studied by Law and Azman-Saini, Asiama and Mobolaji (2015), Herger, Filippidis and Katrakilidis (2014). Law and Azman-Saini (2012, pp. 217-220) in their work highlighted the positive role of institutions in banking activities development. They emphasised the high-quality institutional environment is a defining factor in enormous growth in the banking sector in developed and developing countries. In contrary, Asiama and Mobolaji explained the negative impact of inefficient and ineffective institutions on banking activities growth (Asiama \& Mobolaji, 2015). Currently, the best measure of institutional efficiency in international level is an institutional quality index (IQI) developed by World Bank which ranks 191 different countries in terms of the rule of law, corruption, voice and accountability, freedom of the press, global competitiveness, economic freedom and doing business. Table 2 provides the raking of emerging countries in terms of institutional quality in 2017.

Second, the theory of law and finance is closely related to institutions and reveal the importance of law and legal systems in the development of banking activities. The relationship between law and development of banking activities was researched widely. Coyle and Turner (2013, pp. 810-813) stated that if right and appropriate law is as itself guarantee for the development of banking activities. The regulation of the financial market in emerging economies must deal with institutional constraints to promote financial stability. In emerging economies, the banks are mainly regulated through capital requirements, resolution mechanisms on failing banks, increasing transparency, liquidity risk and leverage management, and coordination among regulations (Eswar, 2017).

Third, the concept of financial liberalisation developed by McKinnon and Shaw emphasises on financial liberalisation and consequent possibilities of banking activities development. The banking sector is considered as liberalised
Table 2

Institutional quality index of emerging market economies in 2017

\begin{tabular}{clcc}
\hline & \multicolumn{1}{c}{ Country } & IQI score & Ranking \\
\hline 1 & Argentina & 0.3082 & 138 \\
2 & Brazil & 0.4397 & 104 \\
3 & Czech Republic & 0.8181 & 25 \\
4 & China & 0.3727 & 118 \\
5 & Turkey & 0.4903 & 91 \\
6 & India & 0.4940 & 90 \\
7 & Indonesia & 0.5114 & 86 \\
8 & Malaysia & 0.6478 & 53 \\
9 & Nigeria & 0.2480 & 151 \\
10 & Republic of Korea & 0.7842 & 29 \\
11 & Poland & 0.7861 & 28 \\
12 & Russian & 0.3497 & 126 \\
& Federation & & 94 \\
13 & Thailand & 0.4790 & 85 \\
14 & Philippines & 0.5148 & 59 \\
15 & South Africa & 0.5923 & \\
\hline
\end{tabular}

Source: Institutional quality index in 2017.

when the restrictions imposed on its activities by the government and other institutions are eliminated, and capital flows are permitted. But the liberalisation of banking activities does not necessarily lead to the development of banking activities, i.e. the most of developed countries experienced crises as a result of liberalisation. Atiq and Haque (2013) established that financial liberalisation should be at an appropriate level, not to restrain banking sector development. Whereas, Ahmed (2013, pp. 261-265) in his work highlighted the positive effect of financial liberalisation in most of the emerging countries by examining by means of empirical assessment. Banking Z-score measures the extent of liberalisation of the individual country's banking sector, which primarily establishes the probability of bank default. It is calculated as Z-score of every bank in the country and then weighted as average for the overall banking sector. Higher the Z-score higher the process of liberalisation and vice versa. The Z-scores for banking activities of emerging market countries 
Table 3

Z-score of emerging market economies in 2017

\begin{tabular}{|c|c|c|}
\hline & Country & Z-score \\
\hline 1 & Argentina & 6.83 \\
\hline 2 & Brazil & 15.21 \\
\hline 3 & Czech Republic & 13.93 \\
\hline 4 & China & 20.83 \\
\hline 5 & Turkey & 8.07 \\
\hline 6 & India & 18.17 \\
\hline 7 & Indonesia & 6.08 \\
\hline 8 & Malaysia & 16.31 \\
\hline 9 & Nigeria & 15.44 \\
\hline 10 & Republic of Korea & 10.2 \\
\hline 11 & Poland & 8.47 \\
\hline 12 & Russian Federation & 5.82 \\
\hline 13 & Thailand & 7.33 \\
\hline 14 & Philippines & 17.74 \\
\hline \multirow[t]{2}{*}{15} & South Africa & 14.69 \\
\hline & World average & 12.67 \\
\hline
\end{tabular}

Source: Bank Z-score. World Bank, 2017.

https://databank.worldbank.org/data/reports. aspx?source $=1250 \&$ series $=$ GFDD.SI.01.

shows the favorable result for eight countries out of selected 15 (see Table 3). Also, for most emerging market countries' banking sector, the Z-scores are increasing from 2012.

Fourth, interest group theory postulates the importance of macroeconomic factors on the development of the financial sector, i.e. openness to trade and capital flows to the country. In providing their significance for encouraging financial development, man researchers highlighted that only a combination of both of them promotes banking activities development. Studies that especially emphasised the role of trade and capital flows for banking activities development are Mahawiya, Andrianaivo and Yartey. For emerging countries, the openness to capital and trade flows already at a high level to most countries. Trade and financial openness indexes measure the degree on which country is exposed to foreign trade and capital. These indexes developed by the IMF are presented in Table 4 for emerging economies in 2017.
Table 4

Trade and financial openness index for emerging countries

\begin{tabular}{clcc}
\hline & \multicolumn{1}{c}{ Country } & TOI (\%) & FOI \\
\hline 1 & Argentina & 25.02 & 0.05 \\
2 & Brazil & 24.12 & 0.1 \\
3 & Czech Republic & 151.70 & 0.7 \\
4 & China & 37.80 & 0 \\
5 & Turkey & 54.12 & 0.7 \\
6 & India & 41.07 & 0.1 \\
7 & Indonesia & 39.54 & 0.3 \\
8 & Malaysia & 135.84 & 0.2 \\
9 & Nigeria & 26.35 & 0.9 \\
10 & Republic of Korea & 80.78 & 0.9 \\
11 & Poland & 104.56 & 0.2 \\
12 & Russian Federation & 46.73 & 0.55 \\
13 & Thailand & 122.80 & 0.05 \\
14 & Philippines & 71.83 & 0.1 \\
15 & South Africa & 58.18 & 0.25 \\
\hline
\end{tabular}

Source: UNCTAD Statistics. UNCTAD, 2017. https://stats. unctad.org/handbook/MerchandiseTrade/Indicators.html.

Fifth, inflation and finance theory is the only theory that proposes the factor which has a strong negative impact on the development of the financial sector. Inflation can be described as a persistent rise in the price and defines the overall macroeconomic stability. Kim and Lin (2013, pp. 343-345) in their work stated that high inflation rates discourage banks from providing long-term credit and causes a reduction in the allocation of resources. But Huybens and Smith, in their empirical work, highlighted the point that when the inflation rate reaches 15 per cent, the negative effect of inflation in banking development reduces. In this context, the point of view of Ayadi is essential, i.e. he discovered the lesser negative effect of inflation in emerging countries with capital flows openness (Ayadi \& Naceur, 2015). Figure 1 shows the relationship between economic growth of emerging economies and inflation rates, which apparently represents reverse dependence, assuming in high eco- 


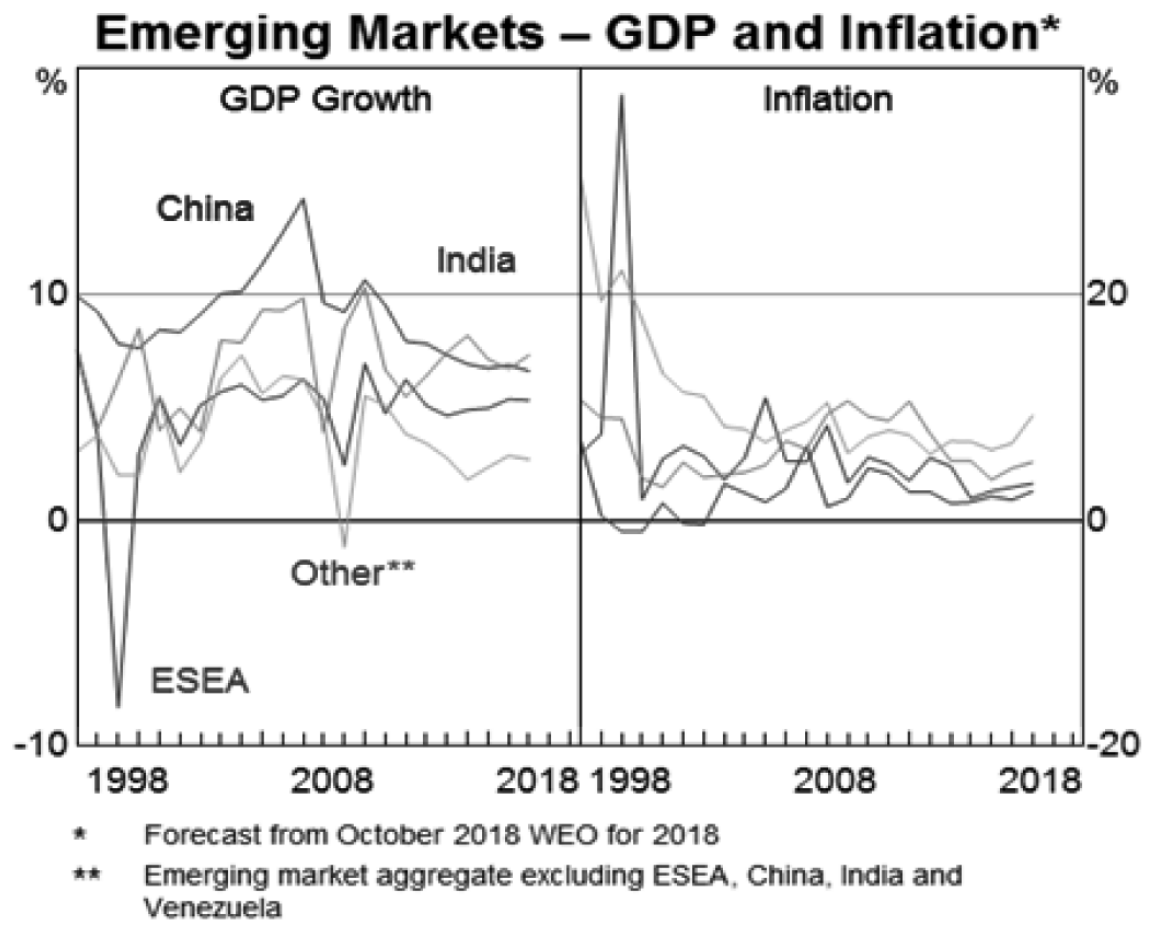

Figure 1. Emerging economies growth and the inflation rate

Source: IMF, RBA.

nomic growth corresponds to the development of banking activities.

There are many other determinants, including income level, government, culture, democracy, and human capital which would affect the banking development. Theoretically, all these determinants regarded to have a favourable influence on the development of the financial sector. The effects of each determinant can be summarised as represented in Table 5. Not all determinants have a direct positive impact on banking development, i.e. some determinants which have a positive effect on developed countries' banking have a negative impact on emerging market banking activities.

\section{The Banking Activities Performance in Emerging Market Economies}

The banking performance is a measure of profitability, stability and efficiency, the importance of which increased after the global financial crisis of 2008. Even though banking profitability has shrunk after the global financial crisis in both developed and emerging countries, it is still the best measure of bank performance. The empirical studies on bank profitability can be divided into two directions: analysis of banking profitability in multiple countries and analysis on the example of
Table 5

The effects of the main determinants of banking activities development for emerging market countries

\begin{tabular}{ll}
\hline \multicolumn{1}{c}{ Main determinants } & $\begin{array}{c}\text { Effect on banking } \\
\text { development }\end{array}$ \\
\hline $\begin{array}{l}\text { Institutional quality } \\
\text { Legal system and }\end{array}$ & Positive \\
Liberalisation & Negative/Positive \\
$\begin{array}{l}\text { Trade and financial } \\
\text { openness }\end{array}$ & Positive \\
Economic growth & Positive/Negative \\
Inflation & Positive \\
\hline
\end{tabular}

Source: The author.

a single country. In other words, there are a few studies on emerging market countries. But the studies of the individual emerging country provide evidence that risk and competition affect profitability as in Table 6 .

The banking profitability is measured either by return on asset or return on equity. Return on asset (ROA) is the simplest measure of profitability, which reflects the ability of the bank to generate profit from asset management. It is calculated as the ratio of net income before 
Table 6

The empirical studies on bank profitability of emerging market economies

\begin{tabular}{lll}
\hline \multicolumn{1}{c}{ Study references } & \multicolumn{1}{c}{ Banking sector investigated } & \multicolumn{1}{c}{ Main findings } \\
\hline $\begin{array}{l}\text { Mirzaei A., Moore T., Liu } \\
\text { G. (2013) }\end{array}$ & $\begin{array}{l}\text { Emerging countries banking } \\
\text { sector (Czech Republic, Poland, } \\
\text { Turkey) }\end{array}$ & $\begin{array}{l}\text { Market share and concentration have an } \\
\text { insignificant and negative correlation with } \\
\text { bank profitability. }\end{array}$ \\
Sufian F. (2011) & South Korean banking sector & $\begin{array}{l}\text { Risk has a negative impact on bank } \\
\text { profitability. }\end{array}$ \\
Liu H., Wilson J. (2010) & Japanese banking sector & $\begin{array}{l}\text { Higher profitability tends to have banks } \\
\text { with lower risks, greater capital, and higher } \\
\text { efficiency. }\end{array}$ \\
$\begin{array}{l}\text { Sufian F., Chong R. } \\
\text { (2012) }\end{array}$ & Philippine banking sector & $\begin{array}{l}\text { Risk and bank profitability have a negative } \\
\text { correlation. }\end{array}$ \\
Tan Y., Floros C. (2012) & Chinese banking sector & $\begin{array}{l}\text { Taxation and GDP growth rate have a negative } \\
\text { impact on bank profitability. }\end{array}$ \\
\hline
\end{tabular}

Source: The author.

Table 7

Bank profitability in selected emerging market countries for 2015-2017

\begin{tabular}{|c|c|c|c|c|c|c|}
\hline \multirow{2}{*}{ Country } & \multicolumn{3}{|c|}{ ROA (\%) } & \multicolumn{3}{|c|}{ ROE (\%) } \\
\hline & 2015 & 2016 & 2017 & 2015 & 2016 & 2017 \\
\hline Argentina & 3.59 & 3.22 & 3.38 & 30.82 & 26.50 & 28.54 \\
\hline Brazil & 1.06 & 0.92 & 1.43 & 13.89 & 11.16 & 15.47 \\
\hline Czech Republic & 1.26 & 1.32 & 1.42 & 12.04 & 12.25 & 13.78 \\
\hline China & 1.09 & 1.54 & 0.96 & 16.99 & 22.44 & 13.83 \\
\hline Turkey & 1.34 & 1.10 & 1.39 & 12.38 & 10.02 & 12.77 \\
\hline India & 0.75 & 0.31 & 0.47 & 10.61 & 4.24 & 6.17 \\
\hline Indonesia & 2.16 & 1.75 & 1.72 & 17.35 & 13.35 & 11.93 \\
\hline Malaysia & 1.36 & 0.93 & 1.04 & 12.67 & 9.09 & 10.56 \\
\hline Nigeria & 2.09 & 1.47 & 1.53 & 14.88 & 10.14 & 10.69 \\
\hline Republic of Korea & 0.41 & 0.32 & 0.48 & 5.16 & 4.24 & 6.73 \\
\hline Poland & 1.07 & 0.85 & 0.96 & 9.59 & 7.56 & 8.6 \\
\hline Russian Federation & 1.00 & 1.00 & 0.49 & 8.68 & 8.68 & 5.93 \\
\hline Thailand & 1.39 & 1.13 & 1.16 & 12.14 & 9.53 & 9.28 \\
\hline Philippines & 1.27 & 1.14 & 1.19 & 12.22 & 10.62 & 10.89 \\
\hline South Africa & 0.90 & 0.91 & 1.19 & 12.34 & 15.42 & 15.46 \\
\hline World average & 1.19 & 1.02 & 1.02 & 12.21 & 10.23 & 10.23 \\
\hline
\end{tabular}

Source: World bank's Global Financial Development Database (GFDD), 2018. https://data.worldbank.org/indicator/FB.AST.NPER. ZS?view=chart. 
Real loan growth per bank

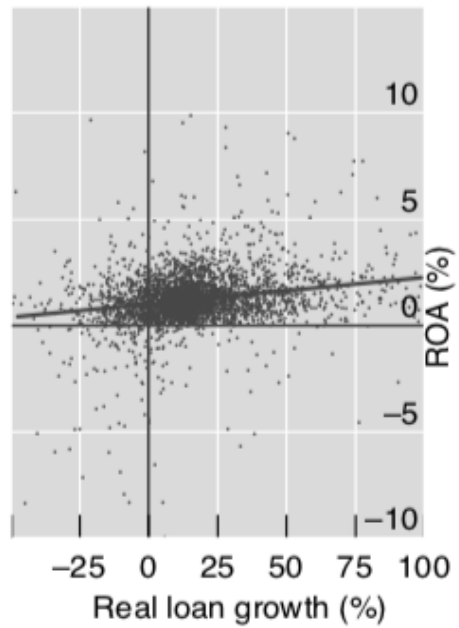

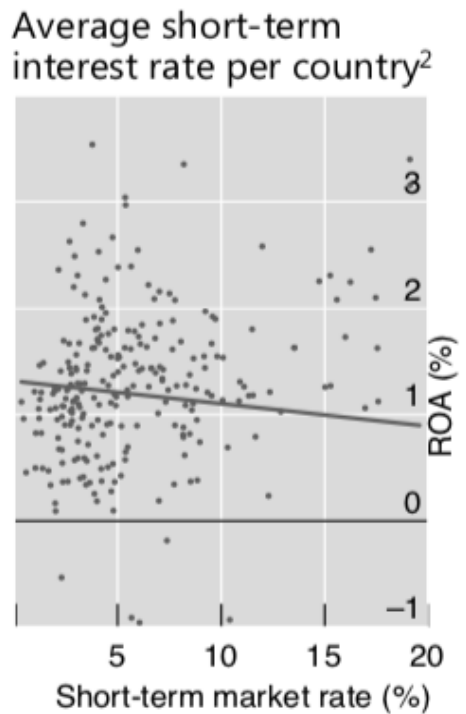

Figure 2. The correlation of ROA with different factors

Source: Kohlscheen \& Murcia, 2018, pp. 6-9.

extraordinary items and taxes to an average asset for the period. Bank profitability in emerging economies was an upward trend until 2007, but it extremely high in comparison with developed countries. The current average of banking industry ROA is 1.12 per cent and 1.02 per cent for banks with an asset less than $\$ 1$ billion ${ }^{3}$. Thus, in our analysis, the measure of 1.02 per cent is more appropriate taking into account that most of the banks in the emerging market, excluding Chinese largest banks with assets of $\$ 4$ trillion individually ${ }^{4}$. Return on equity (ROE) in its turn is a measure of net income generated by invested capital of shareholders. It is calculated by dividing net income before extraordinary things and taxes to average capital. The average ROE for the banking industry is 10.34 per cent for large institutions and 10.23 per cent for smaller, which is suitable for emerging market banks (Table 7).

By comparison with average ROA and ROE, the measure of ROE is more favourable than ROA in emerging market banks. Despite this fact, ROA and ROE of emerging market banks are very promising. Mostly, bank performance in emerging markets is affected by credit growth, long-term interest rate, and by short-term inter-

\footnotetext{
${ }^{3}$ Average ROA and ROE for banking industry. Weiss Rating, 2018. https://greyhouse.weissratings.com/ROA-ROE-andWhat-These-Key-Measures-Mean-for-YOUR-Bank.

${ }^{4}$ Biggest emerging market banks 2018. Global finance, 2018. https://www.gfmag.com/magazine/november-2018/biggestbanks-emerging-markets.
}

est rate and GDP growth to less extent. In other words, bank profitability in emerging markets is influenced more by credit growth. Figure 2 illustrates the correlation of real loan growth, short-term and long-term rate with ROA growth in selected emerging countries. Bank loan growth per bank and long-term interest have a strong positive relationship with ROA, while short-term interest rate causes a decrease in ROA due to funding cost.

The GDP growth effect on profitability is less than credit growth but influences both ROA and ROE. The relationship between GDP growth with ROA and ROE using the quadratic and linear model is represented in Figure 3. The concave curve describing the relationship between ROE and ROA with GDP growth (yellow and blue lines) is similar to the linear curve (red line) indicating a positive correlation of both ROA and ROE with GDP growth. The exception is strong negative GDP growth, where ROE is significantly sensitive to negative GDP growth indicating high relevance.

It is possible to measure the bank stability in terms of net interest margin, non-performing loans to gross loans and liquid assets to deposits and short-term funding (Baum, Pundit \& Ramayandi, 2018, pp. 4-7). The factors influencing banking stability is discussed in many academic and regulatory circles in different countries. These works highlight competition, concentration, market structure and derivatives role 
Table 8

The empirical studies on bank stability of emerging market economies

\begin{tabular}{|c|c|c|}
\hline Study references & Banking sector investigated & Main findings \\
\hline $\begin{array}{l}\text { Fu X., Lin Y., Monyleux P. } \\
(2013)\end{array}$ & $\begin{array}{l}\text { Asian banking sector (China, } \\
\text { Indonesia, South Korea, Malaysia, } \\
\text { Singapore, Thailand, Taiwan, } \\
\text { Philippines) }\end{array}$ & $\begin{array}{l}\text { Bank concentration is no sufficient } \\
\text { measure of competitiveness. } \\
\text { Also, competition-stability and } \\
\text { competition-fragility relationships } \\
\text { are both true }\end{array}$ \\
\hline $\begin{array}{l}\text { Bermpei T., Kalyvas A., } \\
\text { Nguyen T. (2018) }\end{array}$ & $\begin{array}{l}\text { Emerging countries banking sector } \\
\text { (Argentina, Brazil, India, Indonesia, } \\
\text { Malaysia, Russian Federation, South } \\
\text { Africa, Thailand) }\end{array}$ & $\begin{array}{l}\text { Bank regulation and institutional } \\
\text { quality together effectively promote } \\
\text { bank stability by influencing } \\
\text { profitability rather than bank capital }\end{array}$ \\
\hline $\begin{array}{l}\text { Mohammed A., Wolfe S. } \\
\text { (2013) }\end{array}$ & $\begin{array}{l}\text { Emerging countries banking } \\
\text { sector (Nigeria, South Africa, China, } \\
\text { Philippines, Thailand, South Korea, } \\
\text { India) }\end{array}$ & $\begin{array}{l}\text { Greater competition in the banking } \\
\text { sector and revenue diversification } \\
\text { enhance bank stability }\end{array}$ \\
\hline $\begin{array}{l}\text { Mirzaei A., Moore T., Liu G. } \\
\text { (2013) }\end{array}$ & $\begin{array}{l}\text { Emerging countries banking sector } \\
\text { (Czech Republic, Poland, Turkey) }\end{array}$ & $\begin{array}{l}\text { Market share is positively correlated } \\
\text { with bank stability in emerging } \\
\text { market countries }\end{array}$ \\
\hline Mohamed R. (2015) & $\begin{array}{l}\text { Emerging countries (Brazil, Mexico, } \\
\text { China, India) }\end{array}$ & $\begin{array}{l}\text { The use of option and future } \\
\text { instruments affect negatively on } \\
\text { banking stability }\end{array}$ \\
\hline
\end{tabular}

Source: The author.

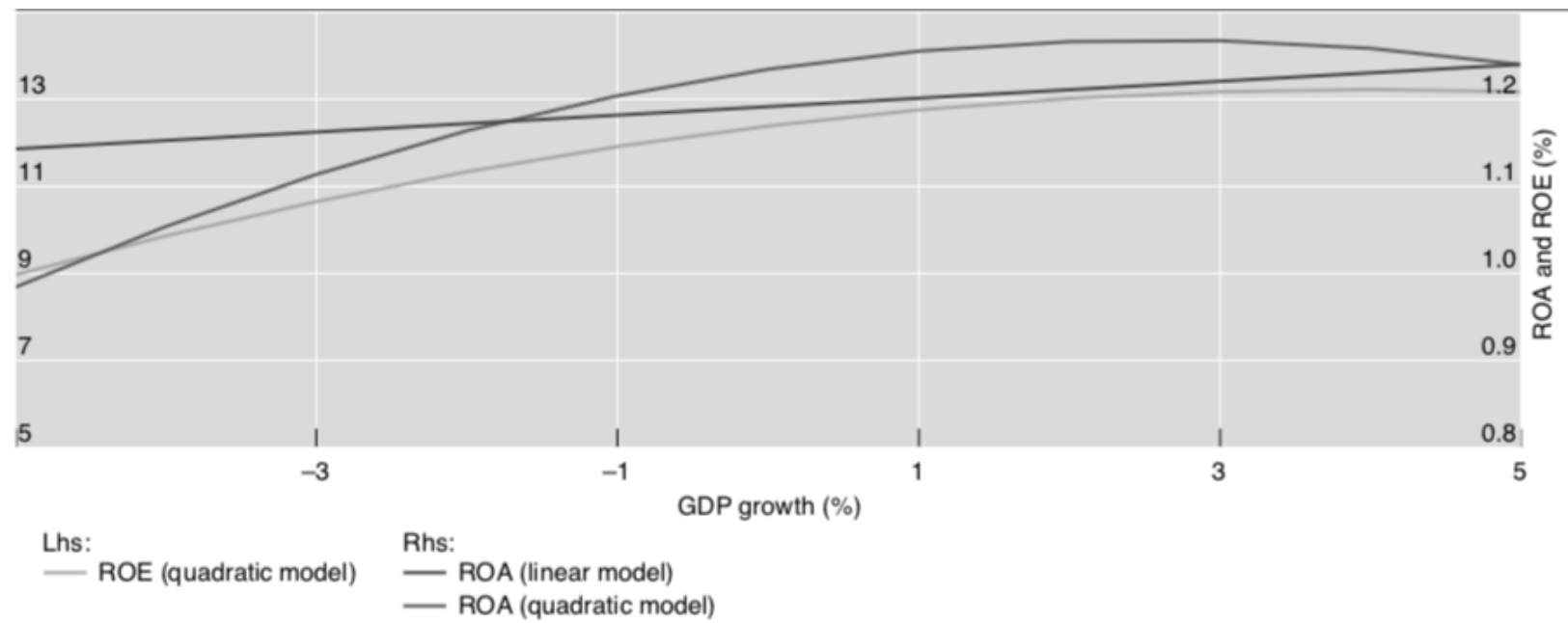

Figure 3. ROE and ROA's correlation with GDP growth in selected emerging economies

Source: Kohlscheen \& Murcia, 2018, pp. 12-15.

on banking stability in emerging economies (Table 8).

Net interest margin (NIM) is a measure of banking stability which expressed as the difference of interest income and interest expense in ratio with interest-earning assets. In other literature, it is also referred to as bank's markup - the difference between weighted average yields of assets and liabilities. A very high or low NIM can create distrust between bank share- holders and cause bank management problems. NIM in emerging market banks volatile, but stable in comparison with world average NIM. Non-performing loan (NPL) is a loan that is close or in the position of default, thus the measure of the non-performing loan to gross loan measures the of asset quality and problems with stability in financial operations. It is calculated as the ratio of non-performing loan to total loan on the balance sheet, including 
Table 1.9

Bank stability in selected emerging market countries for 2015-2017

\begin{tabular}{|c|c|c|c|c|c|c|c|c|c|}
\hline \multirow[t]{2}{*}{ Country } & \multicolumn{3}{|c|}{ NIM (\%) } & \multicolumn{3}{|c|}{ NPL to gross loans (\%) } & \multicolumn{3}{|c|}{$\begin{array}{l}\text { Liquid assets to deposits } \\
\text { and short-term funding } \\
\text { (\%) }\end{array}$} \\
\hline & 2015 & 2016 & 2017 & 2015 & 2016 & 2017 & 2015 & 2016 & 2017 \\
\hline Argentina & 5.91 & 9.20 & 10.35 & 1.99 & 1.74 & 1.84 & 42.92 & 56.23 & 61.27 \\
\hline Brazil & 3.65 & 3.18 & 8.33 & 2.85 & 3.31 & 3.92 & 54.67 & 47.54 & 62.37 \\
\hline Czech Republic & 2.41 & 2.31 & 2.25 & 5.61 & 5.48 & 4.59 & 19.02 & 28.27 & 33.74 \\
\hline China & 2.84 & 4.07 & 2.29 & 4.01 & 3.92 & 3.44 & 16.99 & 15.75 & 13.83 \\
\hline Turkey & 4.15 & 3.80 & 4.00 & 2.99 & 3.11 & 2.84 & 9.85 & 24.38 & 21.97 \\
\hline India & 2.85 & 2.89 & 2.84 & 5.88 & 9.19 & 9.98 & 6.75 & 13.26 & 15.13 \\
\hline Indonesia & 5.68 & 5.70 & 6.39 & 2.43 & 2.89 & 2.56 & 21.94 & 20.62 & 19.41 \\
\hline Malaysia & 2.45 & 1.80 & 1.93 & 1.60 & 1.61 & 1.55 & 20.10 & 18.19 & 17.00 \\
\hline Nigeria & 7.12 & 6.84 & 5.60 & 4.86 & 12.82 & 14.81 & 20.73 & 18.88 & 17.32 \\
\hline Republic of Korea & 2.06 & 1.52 & 1.86 & 0.49 & 0.46 & 0.47 & 8.19 & 11.57 & 10.74 \\
\hline Poland & 2.61 & 2.39 & 2.59 & 4.34 & 4.05 & 3.94 & 13.44 & 11.96 & 9.33 \\
\hline Russian Federation & 4.25 & 1.45 & 4.11 & 8.35 & 9.45 & 10.00 & 44.33 & 40.76 & 34.34 \\
\hline Thailand & 2.95 & 2.72 & 2.94 & 2.68 & 2.99 & 3.07 & 18.27 & 17.84 & 18.07 \\
\hline Philippines & 3.44 & 3.31 & 3.31 & 1.86 & 1.72 & 1.58 & 31.71 & 11.96 & 12.64 \\
\hline South Africa & 3.33 & 2.98 & 3.45 & 3.12 & 2.86 & 2.84 & 22.09 & 24.06 & 23.12 \\
\hline World average & 3.77 & 3.56 & 3.56 & 4.01 & 3.92 & 3.45 & 28.32 & 27.96 & 21.34 \\
\hline
\end{tabular}

Source: World bank's Global Financial Development Database (GFDD), 2018. https://data.worldbank.org/indicator/FB.AST.NPER. ZS?view=chart.

the non-performing loan. NPL to gross loan in emerging economies is characterised by a positive trend, i.e. decreasing in 9 of 15 represented countries. It means that emerging market banks are increasing their ability to enhance asset quality and conduct operation effectively not causing default problems. A liquid asset to deposits and short-term funding is a measure of bank stability that is calculated as easily converting assets divided by the sum of short-term funding and deposits. This indicator is highly volatile in individual emerging market banks, but higher than world average indicating that they are managing assets and liabilities effectively (Table 9) ${ }^{5}$.

Bank efficiency is also one of the bank performance measures, which establishes bank health

\footnotetext{
${ }^{5}$ World bank's Global Financial Development Database (GFDD), 2018. https://data.worldbank.org/indicator/FB.AST.NPER. ZS?view=chart.
} 
Table 10

The empirical studies on bank efficiency of emerging market economies

\begin{tabular}{|c|c|c|}
\hline Study references & Banking sector investigated & Main findings \\
\hline Du K., Sim N. (2016) & $\begin{array}{l}\text { Emerging countries banking sector } \\
\text { (China, India, Indonesia, Russia, } \\
\text { Malaysia, Thailand) }\end{array}$ & $\begin{array}{l}\text { Bank } M \& A \text { has a positive effect on } \\
\text { bank efficiency and mainly benefit } \\
\text { directed to the target bank. }\end{array}$ \\
\hline $\begin{array}{l}\text { Phan H., Daly K., Akhter S. } \\
\text { (2016) }\end{array}$ & $\begin{array}{l}\text { Emerging Asian countries banking } \\
\text { sector (Indonesia, India, Malaysia, } \\
\text { Philippines) }\end{array}$ & $\begin{array}{l}\text { For banks in Indonesia, market } \\
\text { concentration is negatively } \\
\text { associated with bank efficiency. } \\
\text { For banks in Malaysia, India and the } \\
\text { Philippines, market competition is } \\
\text { negatively affecting banks efficiency. }\end{array}$ \\
\hline Partovi E., Matousek R. (2018) & Turkey banking sector & $\begin{array}{l}\text { The presence of NPLs and riskier } \\
\text { portfolio diminish Turkey banking } \\
\text { sector efficiency. }\end{array}$ \\
\hline $\begin{array}{l}\text { Hou X., Wang Q., Zhang Q. } \\
\text { (2014) }\end{array}$ & Chinese banking sector & $\begin{array}{l}\text { There is a positive relationship } \\
\text { between bank efficiency and risk- } \\
\text { taking. }\end{array}$ \\
\hline $\begin{array}{l}\text { Peng J., Jeng V., Wang J., Chen } \\
\text { Y. (2017) }\end{array}$ & Taiwan banking sector & $\begin{array}{l}\text { Both bank efficiency and profitability } \\
\text { are increased with shareholder value } \\
\text { maximisation. }\end{array}$ \\
\hline
\end{tabular}

Source: The author.

and drives the economic growth of the country. The growing studies are concentrating on negative and positive relations of bank efficiency with bank and market characteristics on single and group of countries. For emerging market banks, bank efficiency is studied on the relation of it with bank M\&A, market concentration, banks size, NPLs and risk-taking (Table 10).

Currently, literature highlighted the phenomenon of so-called financial inclusion which is more appropriate for defining bank efficiency (Goel \& Sharma, 2017, pp. 952-954). A financial inclusion system is a system that determines bank efficiency in terms of its accessibility or penetration, availability, and usage. Accessibility dimension of banks for emerging countries is measured in this study by means of several bank branches per 100,000 adults to define the depth of the baking services access. In this case, the number of accounts per capita also can be used, but if the single person holds two and more accounts, the result of the indicator would be improper (Ahamed, 2016, pp. 208-212). Availability dimension of banks is measured by the outreach pervasiveness of financial services in terms of physical banks. It can be expressed by geographical outreach of automated teller machines (ATMs) per $1000 \mathrm{~km}^{2}$, the number of ATMs per 100,000 adults also can be used, but $\mathrm{km}^{2}$ defines geographic availability more precisely (Allen \& Carletti, 2014, pp. 113-117). Usage dimension shows ease and affordability of banking activities, and for measurement transaction cost, ease of transaction and credit plus deposit to GDP can be used (Jiang \& Yao, 2013, pp. 3365-3367). But as banking transactions costs and ease of transaction is different for individual banking institutions, it is more appropriate to use credit plus deposit to GDP as a representative indicator. It represents the extent to which people use credit and deposits for banks, i.e. more efficient banks more credit and deposits in circulation (Table 11). Bank efficiency in emerging market banks is always in a positive trend, i.e. most of the countries are increasing their position. The indicators of accessibility, availability and usage dimensions are not only comparable with average world figures but also characterised with substantial growth.

Bank performance based on bank profitability and stability indicators represent a stable trend for selected 15 countries between 2013 to 2017 (Figure 4). Figure 4 presents the average of each indicator aggregated by comparison with world 
Table 11

Bank efficiency in selected emerging market countries for 2016-2018

\begin{tabular}{|c|c|c|c|c|c|c|c|c|c|}
\hline \multirow{3}{*}{ Country } & \multicolumn{3}{|c|}{ Accessibility } & \multicolumn{3}{|c|}{ Availability } & \multicolumn{3}{|c|}{ Usage } \\
\hline & \multicolumn{3}{|c|}{$\begin{array}{l}\text { Number of bank branches } \\
\text { per } 100,000 \text { adults }\end{array}$} & \multicolumn{3}{|c|}{ ATMs per 1000 km2 } & \multicolumn{3}{|c|}{$\begin{array}{l}\text { Credit plus deposit to GDP } \\
\text { (\%) }\end{array}$} \\
\hline & 2016 & 2017 & 2018 & 2016 & 2017 & 2018 & 2016 & 2017 & 2018 \\
\hline Argentina & 13.17 & 13.37 & 13.42 & 7.19 & 7.22 & 7.22 & 16.53 & 17.79 & 18.77 \\
\hline Brazil & 20.72 & 20.40 & 19.22 & 21.82 & 21.55 & 20.92 & 51.79 & 55.34 & 59.26 \\
\hline Czech Republic & 23.69 & 22.36 & 21.29 & 58.96 & 61.08 & 64.60 & 65.43 & 65.86 & 67.56 \\
\hline China & 37.81 & 37.47 & 38.70 & 65.49 & 92.32 & 98.44 & 44.75 & 43.91 & 44.95 \\
\hline Turkey & 19.19 & 18.14 & 17.39 & 60.05 & 60.25 & 61.51 & 45.07 & 44.47 & 46.33 \\
\hline India & 13.54 & 14.06 & 14.72 & 61.88 & 67.91 & 71.77 & 64.26 & 64.49 & 65.96 \\
\hline Indonesia & 17.75 & 17.39 & 16.89 & 54.81 & 57.09 & 58.87 & 32.82 & 33.71 & 34.39 \\
\hline Malaysia & 10.51 & 10.26 & 10.06 & 35.39 & 34.42 & 34.06 & 124.45 & 123.83 & 119.54 \\
\hline Nigeria & 4.98 & 4.74 & 4.44 & 18.01 & 19.10 & 19.16 & 17.91 & 17.69 & 17.27 \\
\hline $\begin{array}{l}\text { Republic of } \\
\text { Korea }\end{array}$ & 16.76 & 16.26 & 15.45 & 125.45 & 124.48 & 123.42 & 124.02 & 127.44 & 130.29 \\
\hline Poland & 31.14 & 31.02 & 29.29 & 61.64 & 67.05 & 72.32 & 51.94 & 53.59 & 55.83 \\
\hline $\begin{array}{l}\text { Russian } \\
\text { Federation }\end{array}$ & 32.91 & 30.14 & 29.22 & 12.63 & 12.29 & 11.92 & 41.34 & 48.66 & 50.41 \\
\hline Thailand & 12.54 & 12.38 & 11.88 & 124.29 & 125.49 & 131.03 & 114.64 & 115.01 & 114.45 \\
\hline Philippines & 8.79 & 8.87 & 9.05 & 58.08 & 64.00 & 68.01 & 60.46 & 62.79 & 64.15 \\
\hline South Africa & 10.86 & 10.16 & 10.43 & 22.21 & 22.62 & 22.55 & 58.32 & 59.52 & 59.54 \\
\hline World average & 20.63 & 20.72 & 20.74 & 63.12 & 65.70 & 66.14 & 59.45 & 61.35 & 62.16 \\
\hline
\end{tabular}

Source: IMF’s International financial statistics, 2018 https://www.imf.org/external/pubs/ft/fsa/eng/pdf/ch02.pdf.

\section{Bank performance in banks of emerging market economies}

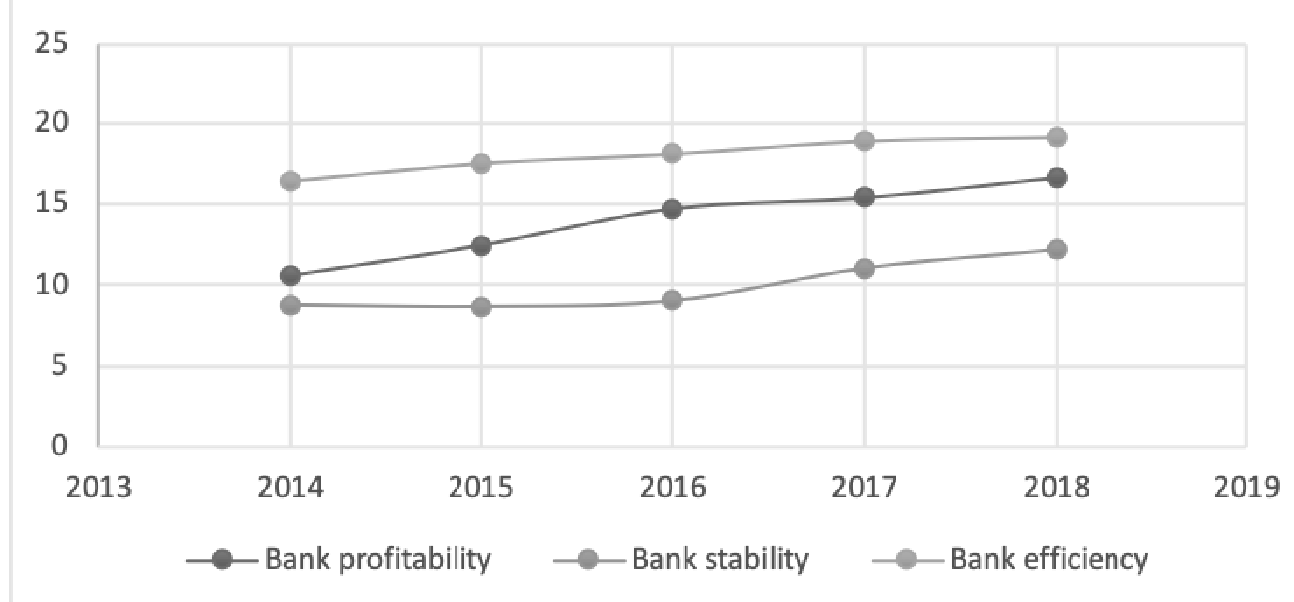

Figure 4. Bank performance in emerging market countries for 2013-2017

Source: The author. 


\section{Percentage of foreign banks to total banks}

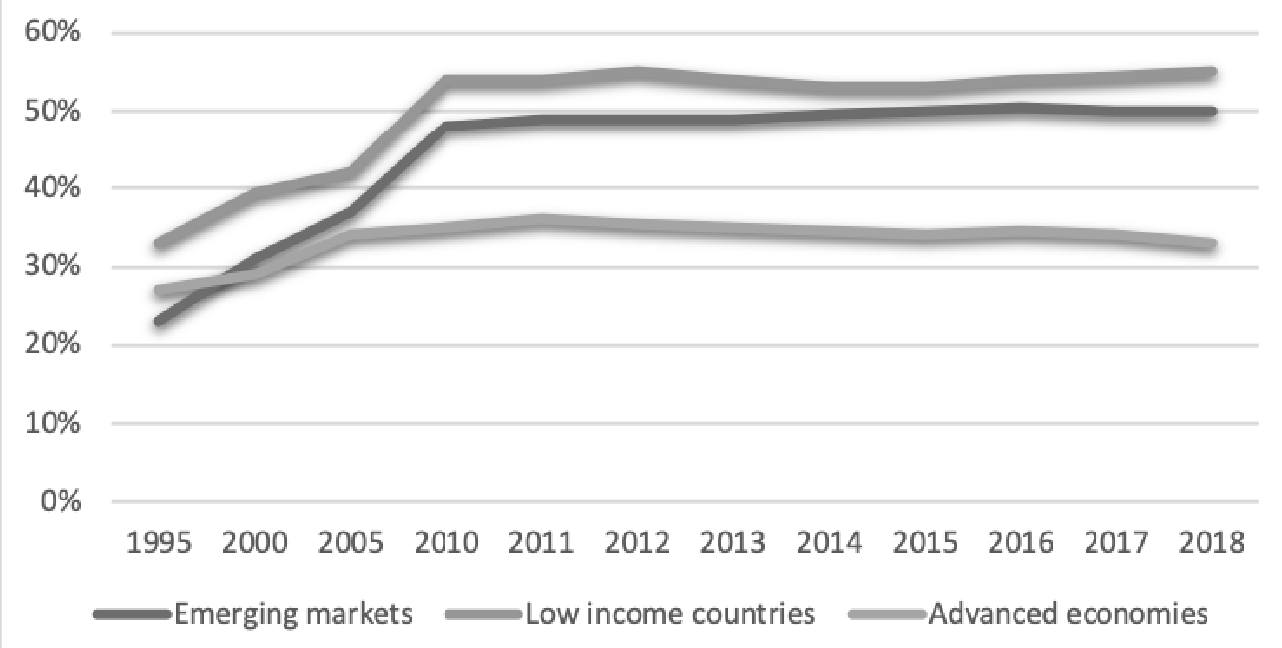

Figure 5. Percentage of foreign banks to total banks

Source: Global Financial Development Report 2017/2018. World Bank, 2018. https://openknowledge.worldbank.org/bitstream/ handle/10986/28482/9781464811487.pdf\#page=41.

average into one measure of bank profitability, stability, and efficiency. As apparently the figure represents, bank efficiency in emerging market banks is high surpassing both bank profitability and stability. As emerging market banking activities highly depend on developed countries financial situation, stability is not guaranteed. Banking activities profitability in the era of fintech revolution and high regulation is considerably presentable with constant growth.

\section{Internationalisation of Emerging Market Banking}

A dramatic shift in wealth distribution is a phenomenon that drives the global economy in modern times. The emerging economies of wealth is increasingly growing during the last years and mainly driven by wealth distribution. The total number of so-called high net worth individuals in emerging economies, mostly in Asian region drives the wealth attraction to emerging economies. In other words, the growth of high net worth individuals is comparative to GDP rate (Marques \& Schneider, 2017, pp. 720-725). Many of these individuals in emerging countries require the same banking services with the same qualities as in developed countries. Despite growth banks of the potential emerging market, a large portion of a population is still not banked at a sufficient level or not banked at all. Thus, the result is a massive expansion of the internationalisation of banks.

In the process of banking internationalisation, financial integration and globalisation are driving force. In emerging market countries, it is characterised by two directions: going abroad and arrival. From 1995 to 2009, the number of foreign banks entering emerging market economies increased by 74 per cent, but from 2010 the trend is considerably slowing (Ghosh, 2017, pp. 84-87). The reasons behind such massive movements of banks are as follows:

To accelerate asset under management to attain a comparable size

To diversify current customers' assets composition

To gather access to new products and technology

To gain more knowledge, more significant presence, and further visibility

To encourage brand recognition.

In other words, foreign banks in host nations are mostly driven by higher profits, diversification of opportunities and accessibility for more expanding services. Also, two main methods of foreign banks entrance to the host country are distinguished as entering through branches and subsidiaries or merger and acquisition of existing banks.

Historically, foreign banks in low-income countries surpass by amount size those in 
Table 12

The empirical studies on foreign banks penetration on emerging market economies

\section{Study references}

Chen J., Zhu L. (2018)

Lee Ch., Chou P. (2018)

Wu J., Chen M., Jeon B. (2017)

Ghosh A. (2016)

Hryckiewicz A., Kowalewski O. (2011)
Banking sector investigated

Main findings
Emerging countries banking sector (Asia, Latin America, Eastern and Central American region countries)

Emerging countries banking sector (China, Czech Republic, Egypt, Indonesia, Philippines, Taiwan)

Emerging countries banking sector (Poland, Czech Republic, Argentina, Brazil, China, India, Indonesia, Thailand, Korea)

Emerging countries banking sector (Argentina, Brazil, China, Czech Republic, Hungary, India, Indonesia, Poland, Qatar)

Emerging countries banking sector (Czech Republic, South Korea, Poland)
Foreign banks penetration using competition encourages banking activities development in Latin America more than in Asia and Europe

Financial market openness improves financial market mobility and liquidity in emerging markets more than in developed markets

An increased presence of foreign banks in emerging market pressures financial stability and implies higher risk than domestic banks

The greater presence of foreign banks and share of loan causes reduction of both profits and costs for domestic banks

Foreign banks' choice of entrance depends on economic characteristics and risk of country, and emerging countries are more attractive in these respects

Source: The author.

advanced and emerging countries. The distinguishing characteristic of foreign banks in emerging market countries in comparison with low-income countries is its persistent and sustainable growth. This massive penetration of foreign banks in emerging and low-income countries can be described by their old banking activities, the inefficiency of information and the exemption from credit allocation regulations which gives foreign banks possibility to gain more profits. Some of the foreign banks in advanced economies in continuous decline, mostly because advanced countries already undergone liberalisation and relation of regulations. Thus, the entrance of new banks to the market will have a marginal effect, i.e. there is an insignificant influence. Therefore, due to the lack of possibilities for development for new participants even through increasing banking sector openness, there is shallow penetration to advanced economies (Figure 5).

Many emerging market banks were slow in internationalisation due to the vast size, attractiveness, and comparative advantages of their domestic market. Currently, this phenomenon is under change by becoming the world's lending force. But few of them are experiencing into neighbouring countries following their large multinationals (MNCs). Their attractiveness is defined by competitive technologies and banking networks that will shape the banking future. But before examining international strategies of emerging market banks, it is essential to understand the environment that develops foreign banks interest to the emerging market.

There is an increasing volume of the literature concentrated on the influence of foreign banks on the emerging market. A presence of 


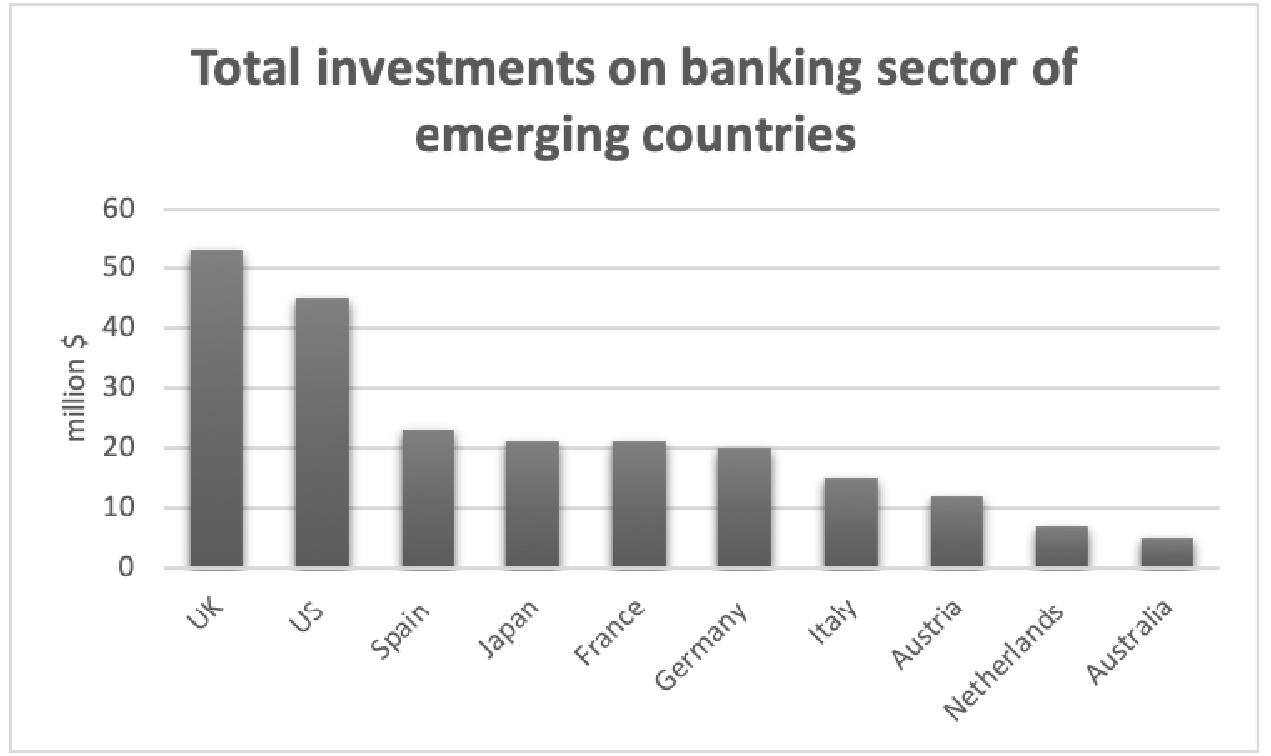

Figure 6. Total investments in the banking sector of emerging market countries for 2018

Source: International banking statistics, 2018. BIS, 2018. https://www.bis.org/statistics/rppb1810.htm.

foreign banks traditionally consider as a positive development for the financial market, but in recent studies, the adverse effects of foreign banks have been revealed. The principal arguments supporting the positive impact of foreign banks are their ability to bring capital, technical improvements and skills, innovation and fostering competition. But current studies highlighted the destabilising role of foreign banks mostly due to increased competition, the transmission of foreign shocks and imposed different risks to the domestic financial system (Table 12).

There are many pieces of evidence that across developed, developing, and emerging countries share of banks owned by foreigners increased. For emerging countries like Brazil, India and China, the state-owned banks play an essential role in the banking sector. Still, after the crisis of 2008-2009, mainly the foreign banks helped to recover from financial distress. A foreign bank is a bank where 50 per cent of overall shares are owned by foreigners. In this respect, Table 13 represents the percentage of foreign bank assets to total bank assets, where the Czech Republic and Poland are substantially owned by foreigners.

Most countries have a share of foreign bank assets to total bank assets of less than the world average. These small shares also can be described by the fact that the number of total as-
Table 13

Percentage of foreign banks assets to total bank assets for 2016-2018

\begin{tabular}{lccc}
\hline \multirow{2}{*}{ Country } & \multicolumn{3}{c}{$\begin{array}{c}\text { Foreign bank assets to total } \\
\text { banks assets (\%) }\end{array}$} \\
\cline { 2 - 4 } & 2016 & 2017 & 2018 \\
\hline Argentina & 27 & 26 & 25 \\
Brazil & 16 & 15 & 15 \\
Czech Republic & 85 & 86 & 87 \\
China & 1 & 1.32 & 1.45 \\
Turkey & 15 & 16 & 17 \\
India & 3 & 3 & 3 \\
Indonesia & 27 & 28 & 29 \\
Malaysia & 17 & 17 & 17 \\
Nigeria & 17.42 & 16.82 & 15.54 \\
Republic of Korea & 7 & 7 & 8 \\
Poland & 56.6 & 45.5 & 44.3 \\
Russian Federation & 7 & 6 & 4 \\
Thailand & 7 & 8 & 9 \\
Philippines & 1 & 1 & 1 \\
South Africa & 24 & 25.5 & 26 \\
World average & 26 & 24.3 & 22.1 \\
\hline
\end{tabular}

Source: Percentage of foreign bank assets to total bank assets. World Bank, 2018. https://databank.worldbank.org/ data/reports.aspx?source=1250\&series=GFDD.0I.16. 
sets of local banks of emerging market countries is considerably increasing over several years.

Several developed countries dominate the amount of total investment made to the banking sector of emerging market countries. Among them, the UK and US are distinguished by colossal investment and increasing interest in emerging market banking activities. Despite numerous obstacles to enter and operate in the new market, especially the banking sector in which high regulation and competition, they adapt to it successfully. Investments in the form of establishment of new banks, including branches and subsidiaries, increased substantially from the US and Japan. The UK, the US, Germany, Australia, and Japan invest in emerging Asia more than in emerging Latin America and Europe. While Spain, Austria, Italy, and the Netherlands more often contribute to emerging Europe and Latin America (Figure 6).

Branches, subsidiaries, and representative offices of foreign banks in emerging countries are mostly established in capital cities and then in less extent in other places. The superiority of different countries foreign banks employing branches, subsidiaries and representative offices can be represented as follows: ${ }^{6}$

Argentina banking sector - HSBC, Deutsche Bank, Santander Bank, BNP Paribas (European banks)

Brazilian banking sector - Barclays, Santander Bank, HSBC, Credit Suisse, BNP Paribas (European banks)

Czech Republic banking sector - BNP Paribas, Deutsche Bank, HSBC, UniCredit Bank, Raiffeisen Bank International (European banks)

Chinese banking sector - Citibank, J.P. Morgan, Morgan Stanley, East-West bank (American banks)

\footnotetext{
${ }^{6}$ Banks around the World, 2018. https://www.relbanks.com/ best-banks.
}

Turkish banking sector - Merrill Lynch Bank, J.P. Morgan Chase, Citibank (American banks) and Deutsche Bank, HSBC, Societe Generale (European banks)

Indian banking sector - Standard Chartered Bank, Barclays Bank, The Royal Bank of Scotland, Deutsche Bank, Societe Generale (European banks) and Shinhan Bank, Woori Bank, KEB Hana Bank, Industrial Bank of Korea (South Korean bank)

Indonesian banking sector - Bank of America, Citibank, J.P. Morgan Chase (American banks)

Malaysian banking sector - Standard Chartered Bank, HSBC, Deutsche Bank, BNP Paribas, Royal Bank of Scotland (European banks)

Nigerian banking sector - Citibank and J.P. Morgan Chase (American banks)

South Korean banking sector - Bank of America, Bank of New York Mellon, Citibank, J.P. Morgan Chase (American banks)

Poland banking sector - BNP Paribas, Credit Agricole Bank, Credit Suisse, DZ Bank, HSBC, Societe Generale (European banks)

Russian banking sector - Raiffeisen Bank International, Societe Generale, Home Credit \& Finance Bank, Credit Europe Bank (European banks)

Thailand banking sector - The Bank of Tokyo-Mitsubishi, Sumitomo Mitsui and Mizuho (Japanese foreign banks)

Philippines banking sector - J.P. Morgan Chase Bank, Citibank, Bank of America, Wells Fargo Bank (American banks)

South African banking sector - Standard Chartered Bank, Societe Generale, Deutsche Bank (European banks).

These list of foreign banks in selected emerging market countries prove the results of Figure 6, which highlights the increasing role of American and European banks in the internationalisation process.

\section{References}

Ahamed, M. (2016). Bank profitability, stability, and efficiency. School of business and management, $208-212$. Ahmed, A. (2013). Effects of financial liberalisation on financial market development and economic performance: empirical assessment on emerging countries. Economic Modeling, 261-265.

Allen, F., Carletti, E. (2014). The African financial development and financial inclusion gaps. Journal of African Economies, 113-117.

Asiama, J., Mobolaji H. (2015). Institutional quality and financial development. ICITI.

Atiq, Z., Haque, M. (2013). Financial development and economic growth: the role of financial liberalisation. Ayadi, R., Naceur, S. (2015). Determinants of financial development across countries. 
Baum, Ch., Pundit, M., Ramayandi, A. (2018). Capital flows and financial stability in emerging economies. Asian Development Bank, pp. 4-7.

Coyle, C., Turner, J. (2013). Law, politics, and financial development. The Journal of Economic History, 810-813.

Eswar, S. (2017). Financial regulation and reforms in emerging markets.

Feyen, E., Levine R. (2013). Financial development in 205 countries. Journal of Financial Perspectives, 17-21.

Filippidis, I., Katrakilidis, C. (2014). Institutions, policy, and banking sector development. Journal of Economics and Finance, 501-507.

Ghosh, A. (2017). How does banking sector globalisation affect economic growth? Illinois Wesleyan University, 84-87.

Goel, S., Sharma, R. (2017). Developing a financial inclusion index for India. Information technology and quantitative management, 952-954.

Jiang, C., Yao, S. (2013). Bank ownership, privatisation, and performance: Evidence from transition country. Journal of Banking and Finance, 3365-3367.

Kim, D., Lin, S. (2013). Dynamic relationship between inflation and financial development. Macroeconomic Dynamics, 343-345.

Kohlscheen, E., Murcia, A. (2018). Determinants of bank profitability in emerging markets. BIS Working Papers, 6-9.

Law, S., Azman-Saini, W. (2012). Institutional quality, governance, and financial development. Economics of Governance, 217-220.

Marques, J., Schneider, S. (2017). Internationalisation strategies of emerging market banks. Indiana University, $720-725$.

Развитие банковской деятельности в странах с формирующейся рыночной экономикой

$$
\text { Отгонтугс Нарангуа }
$$

Бакалавр экономики факультета международных финансов, Департамент мировой экономики и международных финансов, Финансовый университет, Москва, Россия

Аннотация. Цель статьи - анализ специфики развития банковской деятельности в странах

с формирующейся рыночной экономикой. Это важно не только для оценки ее влияния на стимулирование роста развивающихся экономик, но и для установления общего влияния этих процессов на мировой финансовый рынок. Объектом исследования является банковская деятельность, а его предметом влияние развития банковской деятельности на экономический рост данных стран. Обоснован тезис о том, что для этих стран финансовое развитие должно рассматриваться с точки зрения банковской стабильности, конкуренции и экономического роста. Выявлены специфические характеристики, отличающие банковскую деятельность стран с формирующейся рыночной экономикой от развитых стран, путем оценки деятельности банков с использованием критериев стабильности, прибыльности и эффективности.

Ключевые слова: банковская деятельность; формирующаяся рыночная экономика; банковские кризисы; финансовый кризис 2008 г. 